\title{
Crematorium and Vertical Burial in Surabaya as Solution for Water Absorption in Urban Density Problem
}

\author{
Heristama A. Putra ${ }^{1}$, Ima Defiana ${ }^{1}$, and Sri Nastiti N. Ekasiwi ${ }^{1}$
}

\begin{abstract}
Surabaya is the second largest city in Indonesia, which has many problems. Urban density is a major issue which has problems in it, starting from the population density up to the limitations of burial grounds that exist today. Design problem which arises is uniting the facility of funeral homes, crematoriums, and tombs in one area to reduce the mobilization on the road resulting in traffic density. Urban density has resulted in a couple of problems ranging from population density to scarcity of lands. Crematorium and vertical burial therefore become a crucial part of a city. While there has been less open green spaces, crematorium and vertical burial are expected not to reduce the open green spaces. Data scape as a design method is used to obtain design criteria for preliminary design. To obtain a form of structure, combination with the multiple addition geometry method is attempted. A design obtained by making vertical buriel footprint design that is able to provide sufficient absorption area by taking into account the percentage of urban open green space. To create a open green space and water absorption areas by lifting some mass of the building.
\end{abstract}

Keywords - Data scape, Scarcity, Multiple addition, Absorption

\section{INTRODUCTION}

Population density is the main problem in big cities, one of which is Surabaya. Because of population density, there are some of the cemeteries in Surabaya are getting fuller time by time. Most of the burial complexes that exist today are already fully charged, even some burial complexes can no longer receive the bodies. Therefore, a cemetery building which is designed with the concept of vertically upward is very required.

In principle, a graveyard is considered to be an open green area which also serves as water absorption area for urban environment. It can be assumed that all the graveyards in Surabaya hold their multiple functions as control of soil water and open green spaces. The absence of water absorption area coupled with exploited water deposit will lead to emergence of land subsidence with further gives way to flooding. Graveyards function both as burials and park or green zone which also serve as a way of preserving the environment. [1] According to the document entitled "open green space as a garden cityforming Elements", 2005 issued by the Directorate

General of Spatial mentioned that open green space consists of:

1. Private open spaces; the home page, the page's Office, school, place of worship, page page page hospital, hotel, industrial areas, stations, airports,

\section{and farming town.}

2. Public open space; children's recreation, parks/sports field, City Park, Cemetery Park, the green line (the border roads, rivers, railroads, SUTET), and city forest (Conservation city forest, Tourism city forest, Industry city forest).

In the Law on Spatial Planning No. 26 of 2007 Article 29 , paragraph 2 states that the proportion of thirty per cent of the minimum size to guarantee the balance of the ecosystem of the city, a good balance of the hydrological system and the system of microclimates, and ecological systems, which further will increase the availability of clean air community needed, and at the same time can increase the aesthetic value of the city.

Current related designs ground floor tread as a whole on the ground in the size of the footprint available which little space for water absorption. Therefore, the concept to be presented includes raised ground floor of the building so it can serve as absorption areas and open green spaces. Ground floor space can also serve as a circulation path for users that integrate with other buildings.

\section{METHOD}

[4] Design method employed refers to Jormakka (2007), namely the data scape, undertaken by finding the data and then generate the design criteria that the buriel is able to provide open green space and absorption area. There are several ways to get the data, beginning with a location survey which can be done by seeing and analyzing, ranging from site location and condition of the land, the environment, either inside or outside the location of the cemetery. In addition, other data which is used can be a precedent studies, literature, and theories which are related to the problems of population density.

Data and criteria that have been obtained then are realized in a form transformation. [5] During the transformation stage, multiple addition geometry method (Krier, 1988), is also used in which forming methods addition, friction, accumulation and stacking are involved. This method can be applied in the building form to answer a predetermined design criteria.

\section{ANALYSIS}

The choice of location is based on the need of the cemetery area, which are growing crowded and filled in almost all of TPU (public burial) in Surabaya. The selected site location is in the area of public cemetery or TPU Babak Jerawat, Babak Jerawat Village, Pakal 
Subdistrict. [1] Geographically, the location of the site is in the western part of the city of Surabaya. Pakal Subdistrict is located $\pm 4 \mathrm{~m}$ height above sea level.

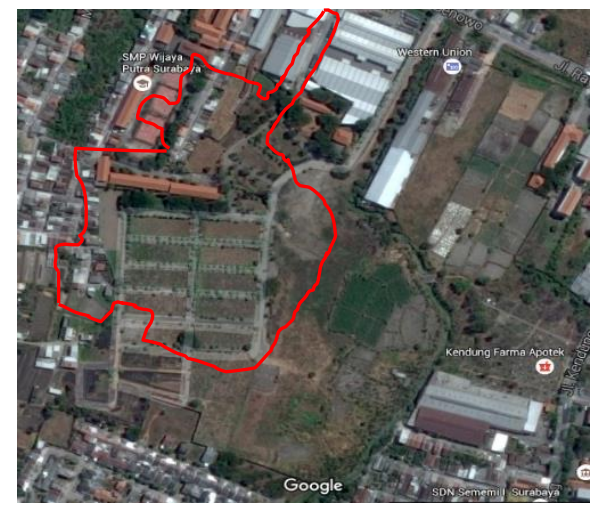

Figure 1. Site location (google earth, 2016)

[2] According to the Law on Spatial Planning No. 26 of 2007 Article 29, it is stated that the open green space is divided into public open green space and private open green space. Public open green space is an open green space which is owned and managed by the local government of the city, which is used for the benefit of society in general. Open green space are city parks, public cemeteries, and green lanes along roads, rivers, and beaches. While private open green space are garden or yard / building belonging to the public / private which are cultivated plants.

[3] According to Hakim (1987), the open space basically is a place that can accommodate the certain activities of the neighborhood residents, either individually or in groups. The form of the open space is very dependent on the pattern and arrangement of the building mass.

The regulation on the cemeteries can be seen in the area of Regulation No. 13 of 2003 on the Management of Cemeteries and Organizing a Funeral Hearse. These regulations were published in the framework of the implementation of the Government Regulation No. 9 of 1987 concerning the provision and use of the land for Cemeteries and the decision of the Minister of Home Affairs number 261989 on Guidelines implementation of Government Regulation No. 9 of 1987. All this suggests the regulations to restrict the use of land as a place of burial grounds and the limitation in respect of the location of the tomb and the ability of the land to the local Government to provide a public cemetery in accordance with the needs of the community of the city of Surabaya.

\section{DESIGN RESULT}

Structure criteria focus on mass planning which is capable of allowing open green spaces and water absorption areas with the burial complex. [6] Archer's model (Rowe, 1991), this process begins with the stage of programming with the results of design objects to a development that has led to a prototype design. Schematic design itself is obtained in the communication phase. Therefore, the design results obtained are as follows:

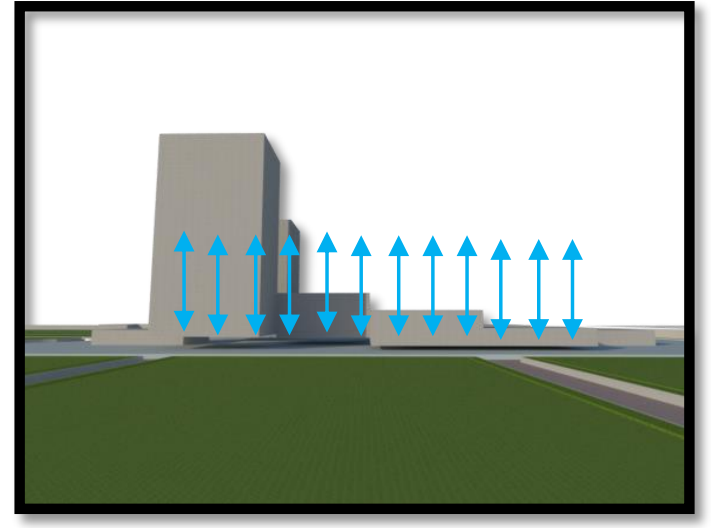

Figure 2. Raised five building

There are five buildings raised (Figure 2), the concept can solve the problems of water absorption because the mass of the tread on the ground is few. By masses of people who raised the proportion is able to provide open green space additional. By masses of people who are raised, it is able to provide the additional proportion of open green space.

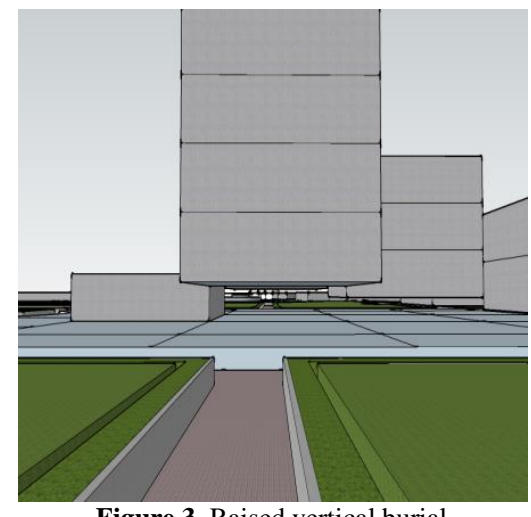

Figure 3. Raised vertical burial

Vertical buriel was appointed with a height of three meters that make a new space on the ground floor (Figure 3 ). These spaces can be enabled as well as line connecting circulation between the masses and the interaction of the user.

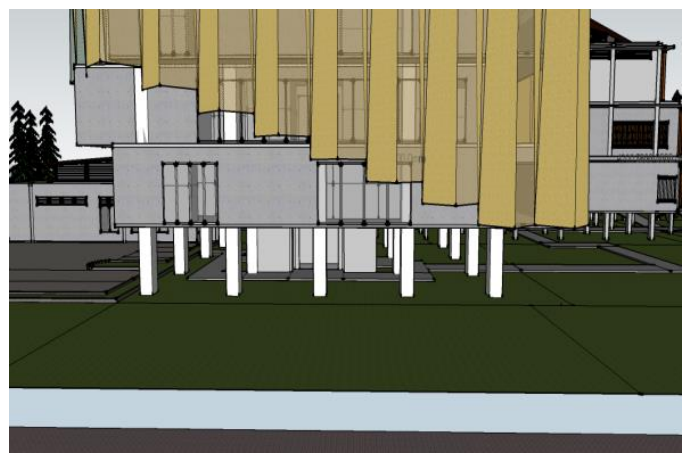

Figure 4. Final outcome of raised burial

The final design in which the entire structure is presented complete with the site planning with open green space (Figure 4). The floor of the raised structure is not massive with columns as major structures when viewed vertically 
The $2^{\text {nd }}$ International Seminar on Science and Technology August $2^{\text {nd }} 2016$, Postgraduate Program Institut Teknologi Sepuluh Nopember, Surabaya, Indonesia

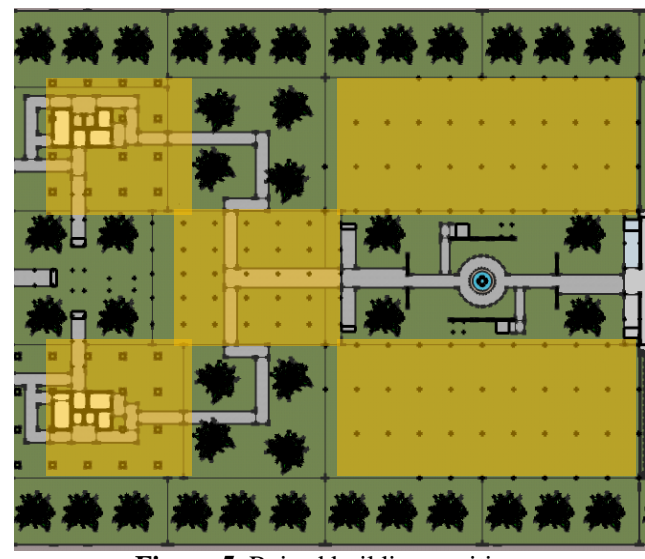

Figure 5. Raised building position

The mass of the building raised giving a lot of absorption areas that serve as open green space. On the ground floor of the building also looks to the order of the columns when viewed horizontally (Figure 5). The pattern of the building was made of this can be seen clearly on a section (Figure 6)

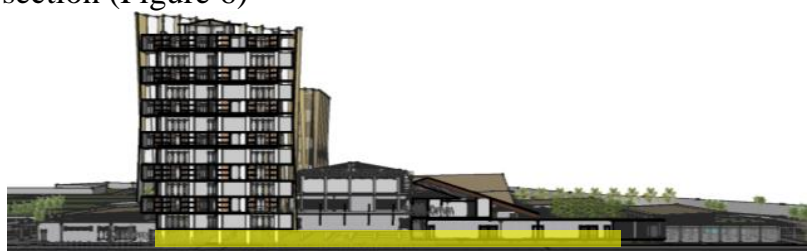

Figure 6. Site Section

The ground floor space function not just as the area of water absorption, but also serves as a path connecting circulation between the mass of the building. It was also given a circulation path roughness in the form of paving (Figure 7). In this area, there are also activities of the visitors who take a rest or relax by giving chair furniture elements along the circulation path.

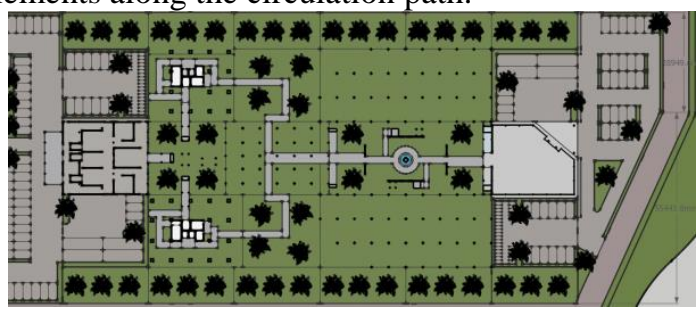

Figure 7. Circulation path

\section{CONCLUSION}

The raised structure mass serves both as an open green space and water absorption area. In general, the raised structure that allows water absorption areas at the bottom of the building does not reduce the area of open spaces of the site. It is the water absorption area that adds to the open green space of the site. space ground floor of the building also serves as a path of circulation with the activity of the user interaction.

\section{REFERENCES}

[1] Dirjen Penataan Ruang. (2005). Ruang Terbuka Hijau sebagai Unsur Pembentuk Kota Taman. Jakarta.

[2] Undang-Undang Penataan Ruang No 26 Tahun 2007 pasal 29 ayat 2. (2007). Jakarta.

[3] Hakim, R. (1987). Unsur Perancangan Dalam Arsitektur Lansekap. Jakarta: Kalibata City News.

[4] Jormakka, K. (2007). Basics Design Methods. Berlin: Birkhauser.

[5] Krier, R. (1988). Architecture Composition. London: Academy Editions.
[6] Rowe, P. G. (1991). Design Thinking. Massachusetts. Massachusetts: The Massachusetts Institute of Technology. 